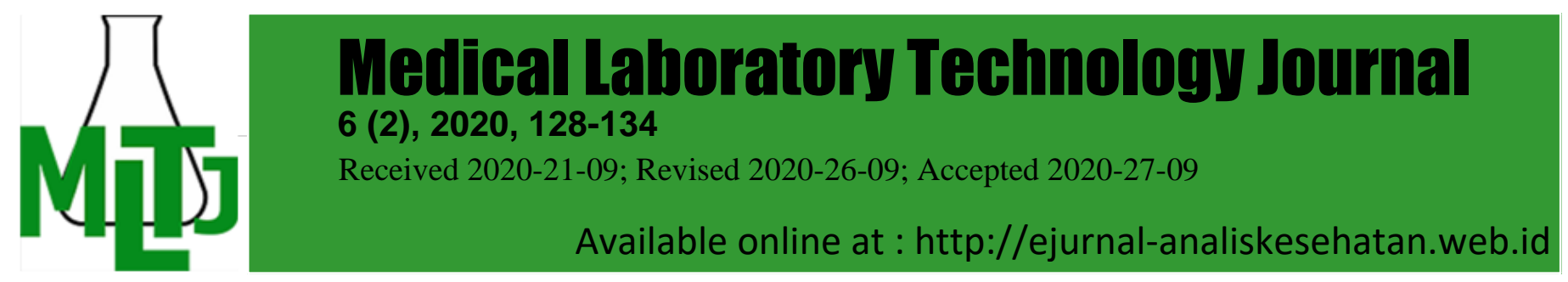

\title{
Evaluation of the Diagnosis of Typhoid Fever Using the Widal Test and the Anti Salmonella typhi IgM Test
}

\author{
*Wahdah Norsiah, Neni Oktiyani \\ Medical Laboratory Technology Poltekkes Kemenkes Banjarmasin. \\ Mistar Cokrokusumo Street 4a Banjarbaru Indonesia \\ *E-mail: wahdahnorsiah1972@gmail.com \\ DOI: 10.31964/mltj.v0i0.327.g147
}

\begin{abstract}
Typhoid fever is a systemic infectious disease caused by Salmonella enteric serotype typhi. Laboratory tests are essential because the clinical symptoms of typhoid fever are not specific. The definitive diagnosis of typhoid fever make by culture isolation of Salmonella typhi, but this test is expensive and takes a long time. Other supporting tests that can do quickly are the Widal and Salmonella typhi lgM tests. This study aimed to determine the suitability between the results of the Widal test and the results of the anti-Salmonella typhi IgM test. This type of research is an observational analytic study determining the sample based on the accidental sampling technique. The number of samples taken was 42 samples. The results showed that the Widal Test in typhoid patients was $76 \%$ positive and $24 \%$ negative. Based on the antiSalmonella typhi IgM test results in typhoid patients, $38 \%$ were positive, and $62 \%$ were negative. The study concluded a fragile agreement between the Widal test results and the results of the anti-Salmonella typhi IgM test. It recommended that the Widal test carried out for the initial examination and a quick community survey. The Tubex test highly recommends for diagnosis.
\end{abstract}

Keywords: typhoid fever; Widal test; anti-Salmonella typhi IgM

\section{INTRODUCTION}

Infectious diseases are one of the leading causes of health problems in developing countries, including Indonesia. Infectious diseases caused by tuberculosis (Rifa'i, A, 2019) and Salmonella a significant obstacle in Indonesia, in addition to the problem of environmental contamination bacteria such as Staphylococcus aureus (Mustika Sari, P, 2019) and Bacillus (Fahani, A., 2019).

An infectious disease caused by Samonella typhi is called typhoid fever, which occurs due to ingesting food or drinks contaminated with salmonella germs. Suspected typhoid fever cases in Indonesia show an increasing trend from year to year, with an average morbidity rate of 500/100,000 and a mortality rate between $0.6-5 \%$ (Depkes $\mathrm{RI}, 2006)$. Typhoid fever is still an obstacle in Indonesia, even though this country is rich in medicinal plants that are antibacterial against Salmonella typhi, such as rosella (Sutiany, A., 2019).

The Widal test can do salmonella detection by determining the agglutinin titer found in the patient's serum against the $\mathrm{O}$ and $\mathrm{H}$ antigens of Salmonella typhi or Salmonella paratyphi antigens. The Widal test can be either false-negative or falsepositive (Depkes RI., 2006).

Salmonella test using DNA-probe and PCR techniques has a high diagnostic value, which has not been widely used for daily practical purposes because it is quite expensive and requires sophisticated equipment. Another sensitive test has Corresponding Author: Wahdah Norsiah 
developed for early detection of acute Salmonella typhi infection, namely the antiSalmonella typhi IgM test. Anti Salmonella typhi IgM test performed to detect antibodies to lipopolysaccharide 09 antigen, which is highly specific for the bacterial antigen. Marleni M. (2014) conducted a study on the accuracy of the TP Tubex test in diagnosing typhoid fever, which showed a sensitivity value of $63 \%$ and $69 \%$, an estimated cost of 43, and a negative predictive value of $83 \%$. Ilham I. (2017) examined IgM anti-Samonella typhi by examining Tubex TP and obtained $65.8 \%$ positive results and $34.2 \%$ negative results.

Dwi Novitasari's research (2015) in 35 inpatients in the internal medicine department and the children's department of Dr. M. Djamil Padang, Indonesia. Shows the results of the suitability of the Widal test with Tubex TF, the kappa value $=0.337$ $(p=0.0046$, so there is a lack of compatibility between the Widal test and Tubex TF. Research by Rao, V. (2018) A total of 794 patient serum samples in India tested using the Salmonella-IgM (Typhi-dot $M$ ) rapid test, the Widal test, and blood culture. Demonstrates the Rapid Salmonella-IgM (Typhi-dot $M$ ) test is significantly more sensitive and specific than the Widal test in diagnosing enteric fever.

The suitability of the results of the examination between these two tests carried out in other areas. Still, it is necessary to know the usefulness of typhoid patients' outcomes at the Community Health Center in Indonesia's Banjarbaru area using the Widal test reagent brand and the anti-Salmonella typhi IgM test, which commonly used at the Community Health Center. This study's purpose was the compatibility between the results of the Widal test and the results of the anti-Salmonella typhi IgM test in typhoid patients in the Banjarbaru area.

\section{MATERIALS AND METHOD}

This research is an observational analytic study with a cross-sectional approach that aims to determine whether there is a match between the Widal test results and the Anti Salmonella typhi IgM test results and approved by the Health Research Ethics Committee. Banjarmasin Health Polytechnic (HREC-PKB) Number: 258/KEPK-PKB/ 2018, the population used in this study were all patients at Sungai Ulin Banjarbaru Community Health Center and Cempaka Banjarbaru inpatient Community Health Center. Determination of the sample based on the accidental sampling technique. The criteria for receiving the sample/inclusion were patients who had a fever, headache, weakness, abdominal pain, vomiting, indigestion, dry skin, chapped lips, typhoid tongue.

The instrument used in this study was a typhoid fever clinical symptom test. Salmonella typhi test using the Widal slide method (Lorne Laboratories) using Salmonella typhi $\mathrm{O}$ and $\mathrm{H}$ suspense antigen, Salmonella paratyphi $\mathrm{A}-\mathrm{O}$, and $\mathrm{A}-\mathrm{H}$, and anti-Salmonella typhi IgM test: Tubex® TF (Biotech).

Research implementation, including clinical history studies and observation by doctors to obtain a clinical picture of typhoid fever. It is said to be positive (+) if there is a clinical picture of typhoid fever and negative (-) if there is no clinical picture of typhoid fever.

Data collected and edits to make to check completeness, continuity, and uniformity of data validation data. Data entered into a computer program, data analysis obtained in the form of primary data, namely the Widal test results with the results of the Anti Salmonella typhi IgM test in typhoid patients tested with the Kappa Agreement. 


\section{RESULTS AND DISCUSSION}

Table 1. Characteristics of the Widal Test Based on Salmonella typhi O Antibody Titer of Typhoid Patients

\begin{tabular}{|c|c|c|c|c|c|c|c|}
\hline \multirow{2}{*}{ No } & \multirow{2}{*}{ Age } & \multicolumn{5}{|c|}{ Salmonella typhi O Antibody Titer } & \multirow[t]{2}{*}{ Total } \\
\hline & & 0 & $1 / 40$ & $1 / 80$ & $1 / 160$ & $1 / 320$ & \\
\hline 1 & Child ( $0-11$ yrs old) & 6 & 0 & 1 & 3 & 1 & 11 \\
\hline 2. & Teen (12-25 yrs old) & 4 & 0 & 2 & 9 & 3 & 18 \\
\hline 3. & Adults (26-45 yrs old) & 3 & 1 & 0 & 0 & 4 & 8 \\
\hline 4. & Elderly ( $\geq 46$ yrs old) & 2 & 0 & 0 & 2 & 1 & 5 \\
\hline Tot & & 16 & 1 & 3 & 14 & 9 & 42 \\
\hline
\end{tabular}

Table 2. Characteristics of the Widal Test Based on Salmonella typhi H Antibody Titer of Typhoid Patients

\begin{tabular}{ccccccccc}
\hline \multirow{2}{*}{ No } & Age & 0 & $1 / 40$ & $1 / 80$ & $1 / 160$ & $1 / 320$ & $1 / 640$ & Total \\
\hline 1. & Child $(0-11$ yrs old $)$ & 6 & 1 & 1 & 2 & 1 & 0 & 11 \\
2. & Teen $(12-25$ yrs old $)$ & 2 & 1 & 8 & 4 & 2 & 1 & 18 \\
3. & Adults $(26-45$ yrs old $)$ & 3 & 0 & 0 & 1 & 4 & 0 & 8 \\
4. & Elderly $(\geq 46$ yrs old $)$ & 0 & 0 & 1 & 1 & 3 & 0 & 5 \\
& Total & 11 & 2 & 10 & 8 & 10 & 1 & 42 \\
\hline
\end{tabular}

Table 3. Anti Salmonella typhi IgM Test Based on Test Results Salmonella typhi O Antibodies

\begin{tabular}{cccc}
\hline No & Titer antibody S. typhi & \multicolumn{2}{c}{ Salmonella typhi IgM } \\
& 0 & Positive & Negative \\
\hline 1. & 0 & 2 & 14 \\
2. & $1 / 40$ & 0 & 0 \\
3. & $1 / 80$ & 2 & 1 \\
4. & $1 / 160$ & 5 & 8 \\
5. & $1 / 320$ & 7 & 3 \\
Total & & 16 & 26 \\
\hline
\end{tabular}

Table 4. Anti Salmonella typhi IgM Test Based on Test Results Salmonella typhi $\mathrm{H}$ Antibodies

\begin{tabular}{cccc}
\hline No & Titer antibody S. typhi & \multicolumn{2}{c}{ Salmonella typhi lgM } \\
& H & Positive & Negative \\
\hline 1. & 0 & 1 & 10 \\
2. & $1 / 40$ & 2 & 0 \\
3. & $1 / 80$ & 5 & 5 \\
4. & $1 / 160$ & 4 & 4 \\
5. & $1 / 320$ & 4 & 6 \\
6. & $1 / 640$ & 0 & 1 \\
Total & & 16 & 26 \\
\hline
\end{tabular}


Table 5. Cross-Tabulation of Widal Test Results with Anti Salmonella typhi IgM Test Results in Typhoid Patients

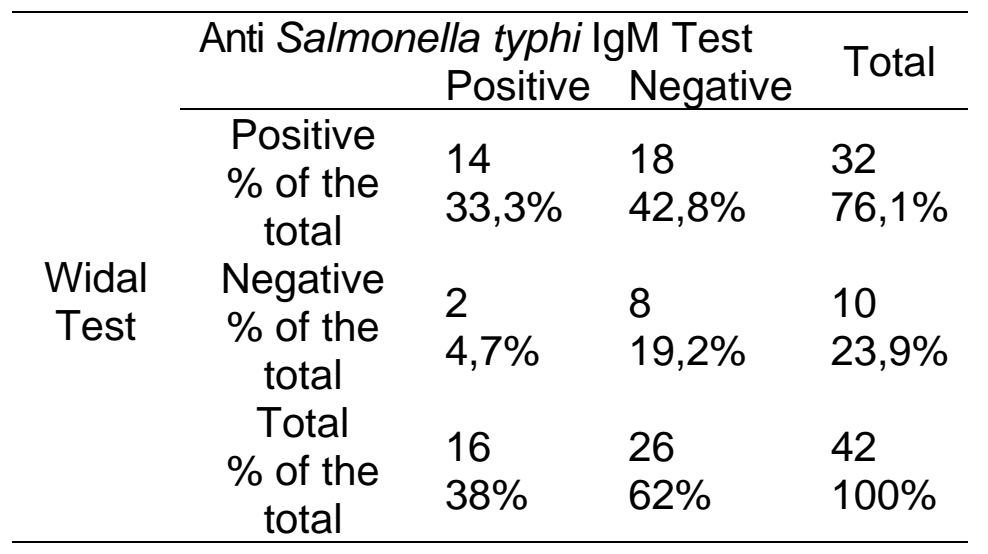

Table 1 shows the results based on the Salmonella typhi $\mathrm{O}$ antibody titer in the most typhoid patients found in the 1/160 titer, namely 14 samples. Table 2 shows the Widal test results based on Salmonella typhi $\mathrm{H}$ antibody titer in typhoid patients with the highest titer of 1/80: ten samples and titer of 1/320: ten models.

Based on the results of the history and physical tests by doctors, of the 42 samples found, 32 samples (76\%) were positive for Widal Test, and ten samples (24\%) were negative Widal Test. Tests performed using Tubex reagent to see Anti Salmonella typhi IgM in typhoid patients showed that $16(38 \%)$ samples were positive, and $26(62 \%)$ samples were negative. To confirm the results of the Widal Test with the IgM Anti Salmonella typhi Test Results: data collected from the two test methods tabulated in a cross table.

From the cross-tabulation of the suitability of the Widal Test results with the Anti Salmonella lgM test results, it knows that the actual positive value or samples that have a positive Widal test result with a positive Anti-Salmonella IgM test result (a) is 14 and the false-positive amount or samples that have The Widal Test is positive, but the negative test result for Anti Salmonella typhi IgM (b) is 18. False-negative values or negative samples Widal Test with positive test results for Anti Salmonella typhi IgM (c) are two. A negative value or valid sample is a test Widal negative and negative Anti Salmonella typhi lgM test result (d) is 8.

Table 6. The results of the Widal Test Parameters with the Anti Salmonella typhi IgM Test Results in Typhoid Patients

\begin{tabular}{clccc}
\hline No & \multicolumn{1}{c}{ Parameter } & Formula & Calculation & Value \\
\hline 1. & Sensitivity & $\mathrm{a} /(\mathrm{a}+\mathrm{c})$ & $14 /(14+2)$ & $87 \%$ \\
2. & Specificity & $\mathrm{d} /(\mathrm{b}+\mathrm{d})$ & $8 /(18+8)$ & $30,8 \%$ \\
3. & Positive Prediction Value & $\mathrm{a} /(\mathrm{a}+\mathrm{b})$ & $14 /(14+18)$ & $43,75 \%$ \\
4. & Negative Prediction Value & $\mathrm{d} /(\mathrm{c}+\mathrm{d})$ & $8 /(2+8)$ & $80 \%$ \\
5. & Compatibility / Accuracy & $(\mathrm{a}+\mathrm{d}) / \mathrm{N}$ & $(14+8) / 42$ & $52,4 \%$ \\
\hline
\end{tabular}

From the calculation of the test parameters (table 6), the Widal test compared to the Anti Salmonella typhi IgM test has a sensitivity of $87 \%$, a specificity of $30.8 \%$, and a positive predictive value $43.75 \%$, a negative predictive value of $80 \%$. Kappa agreement analysis from the results of the Widal test with the Anti Salmonella typhi 
IgM test (table 7) obtained a significance value of 0.177 (>0.05), which means that the compatibility between the Widal test and the Tubex test is not significant. The correlation value is 0.153 , which means that the Widal test and Tubex test show very weak suitability $(0.000-0.199=$ very weak $)$.

Table 7. Kappa Agreement Results in Widal Test with Anti Salmonella typhi IgM Test Results in Typhoid Patients

\begin{tabular}{lcccc}
\hline & Value & $\begin{array}{c}\text { Asymptotic } \\
\text { Standardized } \\
\text { Error }^{\mathrm{a}}\end{array}$ & $\begin{array}{c}\text { Approxim } \\
\text { ate T }\end{array}$ & $\begin{array}{c}\text { Approximate } \\
\text { Significance }\end{array}$ \\
\hline $\begin{array}{l}\text { Measure of } \\
\text { Agreement Kappa } \\
\text { N of Valid Cases }\end{array}$ & .153 & .106 & 1.350 & .177 \\
\hline
\end{tabular}

The Widal Test of 42 samples found that 32 samples (76\%) were positive, and ten samples (24\%) were negative. The Widal test conducted in this study is a single test. According to Khanna, A., 2015, and not in pairs, the Widal test can show agglutination against Salmonella typhi $\mathrm{O}$ antigen in $36 \%$ of healthy population and Salmonella typhi $\mathrm{H}$ antigen in 41 healthy community. Positive titers can be found in healthy communities up to $1: 80$ on $\mathrm{O}$ antigen and 1:160 for $\mathrm{H}$ antigen. So a single Widal test is considered insignificant.

The percentage of IgM Anti Salmonella typhi results in typhoid patients based on the results of 42 typhoid patients, only $16(38 \%)$ were positive after being examined with anti-Salmonella typhi IgM. The Tubex test can detect IgM, so the sensitivity and specificity of the Tubex test are better than the Widal test.

The working principle of this test is the bond between magnetic particles covered by the 09 antigen and IgM antibody. If there is a bond between the 09 antigen and the patient's serum IgM, when the addition of blue latex-coated indicator particles coated with anti-Salmonella typhi LPS antibody, there is no binding with the 09 antigen. As a result, when Tubex place on a buffer magnet, the coated antigen magnetic particles bound to the patient's IgM serum will settle to the bottom. However, the antibody-coated indicator particles did not pay. What is noticeable is that there is no blue discoloration in the Tubex test. This test result shows a positive effect (the patient indicates to have typhoid fever). However, suppose the patient's serum does not contain Salmonella typhi IgM. In that case, there will be an antigen-coated magnetic particle bond with antibody-coated indicator particles so that they place on a magnetic holder; they remain so that a blue to red discoloration occurs on the Tubex test. This test result is negative (the patient does not indicate to have typhoid fever). A quantitative assessment compares the colors formed in the Tubex test with the colors on the Tubex color scale from 0 (red) to 10 (blue). A positive value on the Tubex test supported by clinical signs and symptoms indicates diagnosing typhoid fever (Frankie C H Tam, 2008).

From the Kappa analysis, the results of the Widal test with the results of the Anti Salmonella typhi lgM test in typhoid patients (table 7) obtained a significance value of 0.177 (>0.05), which means that the suitability of the Widal test with the Tubex test is not significant. The correlation value is 0.153 , which means that the Widal test and the Tubex test showed very weak suitability $(0.000-0.191=$ very weak). This result is by Dwi Novitasari's research (2015), which states that there is weak compatibility between the Widal test and the Tubex test. This weak suitability is because the Widal 
test has lower sensitivity and specificity compared to the Tubex test. Research by Soha A Elhawari (2015) showed that the Widal test was positive in 34 patients, giving a sensitivity of $85 \%$, a specificity of $88 \%$, while the Tubex test gave a $95 \%$ sensitivity specificity $90.4 \%$. Research Setiana, G.P. (2015), proving that the Widal test has a sensitivity of $44-77 \%$ specificity up to $50-92 \%$, the Tubex test has a sensitivity of 65 $88 \%$ specificity $63-89 \%$.

Kawano, R. (2007) also shows that the Tubex test has good sensitivity and specificity $(75-80 \%$ and $75-90 \%$, respectively) than the Widal test. This test's sensitivity is due to the use of color particles and its specificity because it detects 09 antigen, which is a specific and typical salmonella antigen. This test can be ideal and can be used for routine checks because it is fast, accurate, easy, and straightforward. According to Tarigan I.N, 2017, considering the specificity and sensitivity of these two tests, the Widal test is recommended to be carried out in the initial examination and community survey. In contrast, the Tubex test highly recommends for diagnosis. Typhoid patients' decision is determined clinically by considering all aspects, including signs and symptoms, physical test results, and supporting products, including Widal and Tubex tests (Tarigan I.N, 2017).

The limitation of this research is the lack of respondents. The study also compared the results between the two tests without comparing the standard gold test for the diagnosis of typhoid fever (culture).

\section{CONCLUSION}

The study concluded a fragile agreement between the Widal test results and the anti-Salmonella typhi IgM test results. It recommends that the Widal test to carry out for the initial examination and a quick community survey. The Tubex test highly recommends for diagnosis.

\section{ACKNOWLEDGMENT}

The author would like to thank those who have helped carry out this research, especially the Poltekkes of the Ministry of Health in Banjarmasin, the Poltekkes Research Unit, the Immunology Laboratory at the Medical Laboratory Technologist Campus, Sungai Ulin Banjarbaru Community Health Center, and the Cempaka Banjarbaru Community Health Center who facilitated this research.

\section{CONFLICT OF INTEREST}

The authors have no potential conflicts of interest concerning this study.

\section{REFERENCES}

Departemen Kesehatan RI. (2006). Keputusan Menteri Kesehatan RI No.364/Menkes/SK/V/2006/ Tentang Pedoman Pengendalian Demam Tifoid. Jakarta : Depkes RI

Dwi, Novitasari. (2015). Kesesuaian Uji Widal, Tubex Tf® Dan Typhidot-M® dengan Skor Nelwan pada Pasien Tersangka Demam Tifoid. Diploma thesis, Universitas Andalas, Indonesia.

Fahani, A., Dwiyanti, RD., Muhlisin. A., (2019). Contamination of Bacillus cereus in Elementary School Snack Food. Tropical Health and Medical Research, 1(2), 5661. https://doi.org/10.35916/thmr.v1i2.10

Frankie C H Tam, Thomas K W Ling, Kam Tak Wong, Danny T M Leung, Raphael C Y Chan, Pak Leong Lim. (2008). The TUBEX test detects not only typhoid- 
specific antibodies but also soluble antigens and whole bacteria. J Med Microbiol, 57(Pt 3), 316-323. doi: 10.1099/jmm.0.47365-0.

Ilham, I., Nugraha, J., \& Purwanta, M. (2017). Deteksi IgM Anti Salmonella Enterica Serovar Typhi dengan Pemeriksaan Tubex TF dan Typhidot-M. Jurnal Biosains Pascasarjana, 19(2). https://doi.org/10.20473/BSN.V19l2.5703

Kawano, R., Leano, S., and Agdamag D. (2007). Comparison of serological test kits for diagnosis of typhoid fever in the Philippines. Journal of clinical microbiology, 45(1), 246-247.

Khanna, A., Khanna, M., \& Gill, K. S. (2015). Comparative evaluation of tubex TF(Inhibition magnetic binding immunoassay) for typhoid fever in endemic area. Journal of Clinical and Diagnostic Research, 9(11), DC14-DC17. https://doi.org/10.7860/JCDR/2015/15459.6810

Marleni, M., Iriani, Y., Tjuandra, W., \& Theodorus. (2014). Ketepatan Uji Tubex TF ${ }^{\circledR}$ dalam Mendiagnosis Demam Tifoid Anak pada Demam Hari ke-4. Jurnal Kedokteran Dan Kesehatan, 1(1), 7-11

Mustika Sari, P., Lutpiatina, L., Muhlisin. A., (2019). Staphylococcus aureus in Traditional Coconut milk Drinks. Tropical Health and Medical Research, 1(1), 33-38. https://doi.org/10.35916/thmr.v1i1.1

Rao, V. (2018). A Comparative Study Of Rapid Salmonella-Igm Test (Typhi-dot M) And Widal Test In The Diagnosis Of Enteric Fever In A Tertiary Hospital. International Journal Of Current Microbiology And Aplied Sciences.

Rifa'i, A., Muhlisin, A., Lutpiatina L., (2019). Erythrocyte Morphology of Tuberculosis Patients. Tropical Health and Medical Research, 1(1), 10-18. https://doi.org/10.35916/thmr.v1i1.3

Setiana, G.P., Angga P.K. (2016). Perbandingan Metode Diagnosis Demam Tipoid. Farmaka. 4(1). https://doi.org/10.24198/jf.v14i1.11086.g5115

Soha A Elhawari, Mohamed H Mourad. Validity of TUBEX Test versus Widal Test in Detection of Typhoid Fever in Zagazig, Egypt. The Afro-Egyptian Journal of Infectious and Endemic Diseases (AJIED), 5(4), 265-270

Sutiany, A., Dwiyanti, RD., Oktiyani. N. (2019). Inhibition Strength of Rosella (Hibiscus sabdariffa L.) Boiled Water on Salmonella typhi in vitro. Tropical Health and Medical Research,1(2), 62-67. https://doi.org/10.35916/thmr.v1i2.7

Tarigan I.N. (2017). Studi Literatur Efektivitas Tes Widal dan Tubex untuk Diagnosis Tifoid di Daerah Endemik. Access: 25 September 2020, Retrieved from https://www.alomedika.com/studi-literatur-efektivitas-tes-widal-dan-tubex-untukdiagnosis-tifoid-di-daerah-endemik 